\title{
Somatostatin receptors in normal and acromegalic somatotroph cells: the U-turn of the clinician to immunohistochemistry report - a review
}

\author{
Nina Ionovici ${ }^{1}$, Mara Carsote ${ }^{2,3}$, Dana Cristina Terzea ${ }^{3,4)}$, AnCA Mihaela PredesC( ${ }^{5)}$, \\ ANNE-MARIE RAUTEN ${ }^{6}$, MiHAELA POPESCU ${ }^{7)}$ \\ 1) Department of Occupational Medicine, Faculty of Medicine, University of Medicine and Pharmacy of Craiova, \\ Romania \\ 2) Department of Endocrinology, Carol Davila University of Medicine and Pharmacy, Bucharest, Romania \\ 3) Department of Endocrinology, C. I. Parhon National Institute of Endocrinology, Bucharest, Romania \\ 4) Department of Pathology, Onco-Team Diagnostic, Royal Hospital, Bucharest, Romania \\ ${ }^{5)}$ Department of Histology, Faculty of Dental Medicine, University of Medicine and Pharmacy of Craiova, \\ Romania \\ 6) Department of Orthodontics, University of Medicine and Pharmacy of Craiova, Romania \\ 7)Department of Endocrinology, University of Medicine and Pharmacy of Craiova, Romania
}

\begin{abstract}
This is a narrative review of literature introducing somatostatin receptors (SSTRs) as part of understanding the somatotroph cells since they are positive in normal cells but also in tumoral cells as seen in somatotropinoma, a growth hormone (GH)-producing neoplasia, which causes acromegaly. They are five subtypes of SSTRs (1 to 5), which are immunohistochemically positive in different proportions in somatotropinomas. SSTR types 2 and 5 are most frequent in GH-secreting adenomas and they are both targeted by medical therapy with somatostatin analogues (SSTAs) like first generation Octreotide and Lanreotide (mainly targeting SSTR2) and second generation Pasireotide (with highest affinity for SSTR5), thus heterogeneous SSTRs configuration into the tumor explains different pattern of response to treatment and it might predict it once the SSTRs immunostaining is performed. Monoclonal antibodies are used for immunohistochemical detection of SSTRs; currently, a lack of standardization is presented, and scoring systems, such as Volante, H-score or human epidermal growth factor receptor 2 (HER2)score, are applied. Immunoreactive markers like SSTRs are the U-turn in clinical practice regarding somatotropinomas since the configuration of subtypes 2 and 5 explains the responsiveness to medical therapy like SSTA. Further achievement of disease control is imperiously necessary because acromegaly has an increased rate of morbidity and mortality.
\end{abstract}

Keywords: somatostatin receptors, somatotropinomas, immunohistochemistry.

\section{Introduction}

Somatostatin receptors (SSTRs) are part of understanding the somatotroph cells since they are positive in normal cells but also in tumoral cells as seen in somatotropinoma, a growth hormone (GH)-producing neoplasia, which causes acromegaly $[1,2]$. SSTRs ligands are the physiological hormone somatostatin (SST) and the class of drugs designed to be long-acting somatostatin analogues (SSTAs) like first generation Octreotide and Lanreotide and newly introduced in daily endocrine practice Pasireotide, a second generation SSTA, which are used as treatment in acromegaly $[1,2]$. SSTRs are heterogeneously expressed in GH-secreting tumors; SSTAs have different affinities for them, and this becomes a crucial aspect in understanding why some cases of acromegaly have a better response to one generation or another of SSTA [1,3-5].

They are five subtypes of SSTRs; they are immunohistochemically positive in different proportions in somatotropinomas $[4,5]$. The most important immunostaining is for SSTR types 2 and 5 because they are targeted by SSTAs as main medical therapy in acromegaly $[1,4-6]$. SSTR2 expression is lower in pre-treated acromegalic patients with SSTAs and/or GH receptor-blocking medication like Pegvisomant, when compare to drug naïve acromegalic subjects, because therapy induces a down-regulation of SSTRs [3]. Resistance to SSTAs involves signal transduction anomalies of SSTRs [5, 7]. Also, cases with partial response or partial resistance to SSTAs have been described [5]. New biomarkers as immunohistochemistry expression of E-cadherin are under investigation in order to predict the response to SSTAs [7]. Monoclonal antibodies are used for immunohistochemical detection of SSTRs; currently, a lack of standardization is presented and scoring systems, such as Volante, H-score, and human epidermal growth factor receptor 2 (HER2)-score, are used [4, 8].

\section{Aim}

We aimed to introduce general data on a modern topic: the use of SSTRs immunostaining in better understanding the normal function of somatotroph cells, as well as their application in acromegaly, especially when choosing the medical therapy with SSTAs.

This is an open-access article distributed under the terms of a Creative Commons Attribution-NonCommercial-ShareAlike 4.0 International Public License, which permits unrestricted use, adaptation, distribution and reproduction in any medium, non-commercially, provided the new creations are licensed under identical terms as the original work and the original work is properly cited. 


\section{Method}

This is a narrative review of literature based on a PubMed research using as keywords "somatostatin receptor", "acromegaly", "somatostatin analogue", "somatostatin". Most of the papers included are from 2016-2019. The topic is introduced based on a point of view related to immunohistochemistry report, as well as endocrine approach of acromegaly both as diagnosis and therapy. In order to highlight the narrative review, some captures of SSRTs immunohistochemistry, as well as computed tomography (CT) in a case of acromegaly are introduced. All the images are priory unpublished.

\section{General data}

\section{Immunostaining and molecular biology aspects of SSTRs}

SSTR is a $\mathrm{G} \alpha$-protein coupled receptor, which inhibits adenylate cyclase and further decreases cyclic adenosine monophosphate (cAMP) production, thus causing a lowering of calcium into the cell $[1,9]$. SSTRs are activated by SST, which represents an inhibitory polypeptide with 14, respective 28 amino acids, depending on active form, both are derived from a large precursor molecule called preproSST $[9,10]$. SST, a cyclopeptide, is also known as SST-release inhibitory factor [11]. The normal role of hypothalamus-related SST is to inhibit pituitary hormones secretion like GH, thyroid stimulating hormone (TSH), adrenocorticotropic hormone $(\mathrm{ACTH})$ and prolactin $[9$, $10]$.

Some tumors display SSTRs-like neuroendocrine tumors (NETs), rare type of oncocytomas (like spindle cell oncocytoma), thus their immunohistochemical analysis might indicate SSTAs as therapy based on an individual approach, and also it might help understanding tumor progression [12-14]. For instance, down-regulation of SSTR2 subtype in small intestinal NETs is correlated with neoplasia progression at the level of intestinal wall [13]. Further applications of SSTRs are represented by peptide receptor radionuclide therapy (PRRT) as applied in NETs including pheochromocytomas and paragangliomas [14 16]. Also, the assessment of SSTRs configuration is a clue of metastasis identification from a primary tumor, which may display the same configuration as primary lesion or a dedifferentiation process [14, 16-18]. Moreover, immunoblotting assesses and reverse transcription polymerase chain reaction (RT-PCR) for SSTRs recently revealed a different pattern for subtypes 1 and 5 in follicular and anaplastic carcinoma of the thyroid [19]. It seems that increased expression of SSTR2 and SSTR5 is correlated with a poor prognosis in medullary thyroid carcinoma [20].

The large scale of SSTRs-positive tumors makes very useful their immunostaining [21]. Manual assessment of SSTRs is rather complicated and automated evaluation simplified the procedure [21, 22]. Immunohistochemistry report on paraffin sections uses specific monoclonal antibodies against SSTR of either rabbit, rat, and mouse origin $[21,22]$.

\section{Immunohistochemistry of SSTRs in pituitary somatotroph cells}

SSTRs are positive in all pituitary cells including corticotroph, lactotroph and thyrotroph cells, not only somatotroph cells $[9,10]$. Apart from endocrine inhibitory role, SST exerts an influence on cell cycle by inducing apoptosis $[9,10]$. The main effects of SSTRs are introduced in Figure 1.

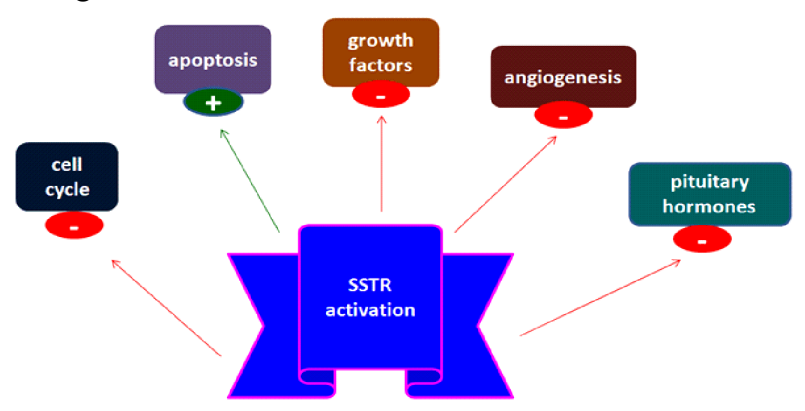

Figure 1 - SST and SSTAs intervention via SSTRs activation at cellular level, as explained in the text. SST: Somatostatin; SSTAs: Somatostatin analogues; SSTRs: Somatostatin receptors.

Somatotropinoma mainly expresses SSTR2, which are targeted by first-line generation SSTA Octreotide and Lanreotide [9, 11]. But the heterogeneity of the SSTRs in the tumor allows only a partial control of acromegaly in $50-70 \%$ of cases $[9,11,23]$. The second line SSTA Pasireotide (SOM230) was recently introduced in medical practice and it has a much higher affinity for SSTR5, thus some tumors are better controlled by second line medical therapy $[11,24]$. The SSTAs affinity for SSTRs, as well as their expression in somatotroph cells, are introduced in Figure 2.

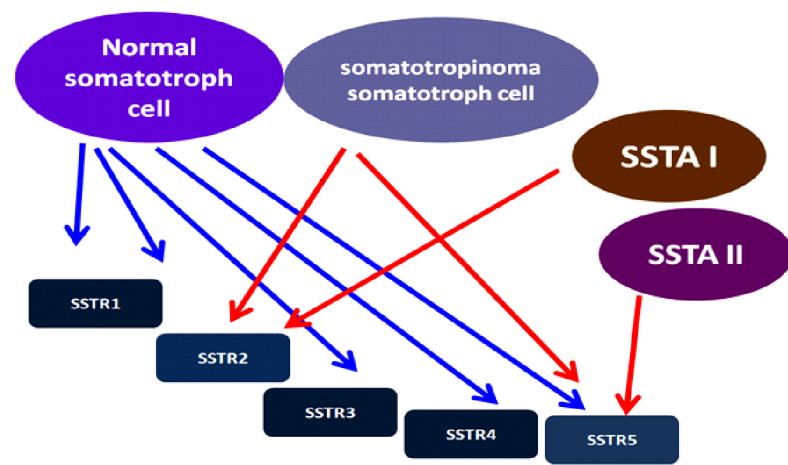

Figure 2 - The expression of SSTRs in normal and tumoral somatotroph cells. SSTAs bind SSTRs with different affinities - the higher binding capacity of each SSTA generation is represented by red arrows. SSTAs: Somatostatin analogues; SSTRs: Somatostatin receptors.

Most current acromegaly protocols of daily endocrine practice include the therapy with long acting Pasireotide only in cases proved as resistant to first line medical treatment like Octreotide or Lanreotide [11, 24, 25]. The activation of SSTRs pathways in somatotroph cells is followed by inhibition of GH secretion (the main effect) and (secondary) GH production and cell proliferation [1, 11]. Most hormonal effects in acromegaly are mediated by SSTR2 and SSTR5, thus their immunostaining in a 
somatotropinoma may be important, while medical therapy also targets SSTR2 and SSTR5 [11,26]. The relationship between SSTRs and SSTAs of first and second generation is introduced in Figure 3. In somatotroph cells of somatotropinoma, an interaction between aryl hydrocarbon receptor-interacting protein $(A I P)$ gene downstream including AIP immunostaining and SSTRs expression might reflect the response to SSTAs [27].

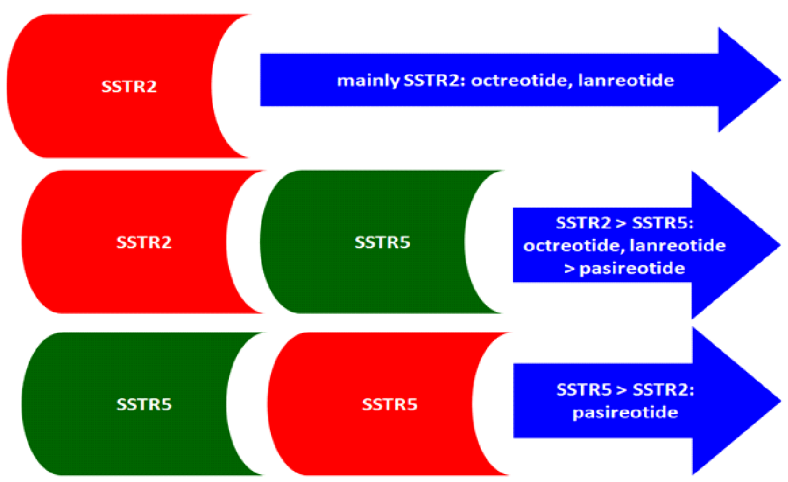

Figure 3 - SSTAs intervention on somatotroph cells of GH-producing adenomas depending on SSTRs expression in tumor. GH: Growth hormone; SSTAs: Somatostatin analogues; SSTRs: Somatostatin receptors.

Pituitary corticotroph cells also express SSTRs including in abnormal conditions, for instance, in corticotropinomas (ACTH-producing adenomas or corticotropinomas which cause Cushing's disease) [9, 24]. In this case, SSTR5 are most frequently seen because SSTR2 are down-regulated by chronic cortisol excess $[9,24]$. Since Pasireotide is a multireceptor-targeted SSTA with a high SSTR5 affinity, it has also been used in Cushing's disease [24-29]. Nonfunctioning pituitary adenomas also express SSTRs but to a lesser extent [30].

Overall, pituitary tumors without or without secretor profile are usually benign masses with a lent rate of development expressing SSTR, such as: somatotropinomas - type 2 and 5 in different ratios (more frequent type 2); corticotropinomas - type 2 and 5 (typically synchronous expression), thyrotropinomas - type 2 with co-expression for SSTR3 and SSR5, prolactinomas - type 1 and 5, nonfunctioning adenomas - mostly SSTR3, followed by SSTR2 and then SSTR5 [23, 31]. The SSTRs expression in functioning and non-functioning pituitary adenomas is introduced in Figure 4.
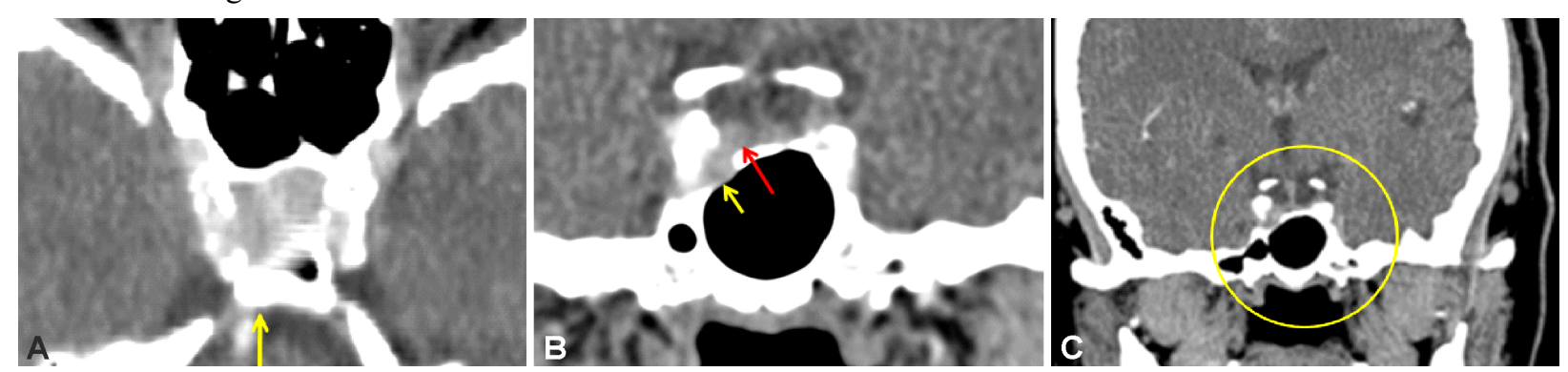

Figure 5 - Pituitary CT (multislice 16, spiral technique) of a 68-year-old acromegalic patient to whom selective hypophysectomy of the microsomatotropinoma was performed. Active post-operatory disease makes the patient candidate for medical therapy. Monthly $20 \mathrm{mg}$ Octreotide LAR ${ }^{\circledR}$ was offered to the patient. See below postoperative aspect of the tumor during first year after surgery at different plans. (Priory unpublished case). (A) Detail of sella turcica. A right microadenoma is presented as postoperative remnant. (B) Yellow arrow: transsphenoidal posthypophysectomy aspect. Red arrow: right microsomatotropinoma after surgery. (C) Frontal plane. Pituitary area after surgery with GH-producing adenoma remnants. CT: Computed tomography; GH: Growth hormone. 


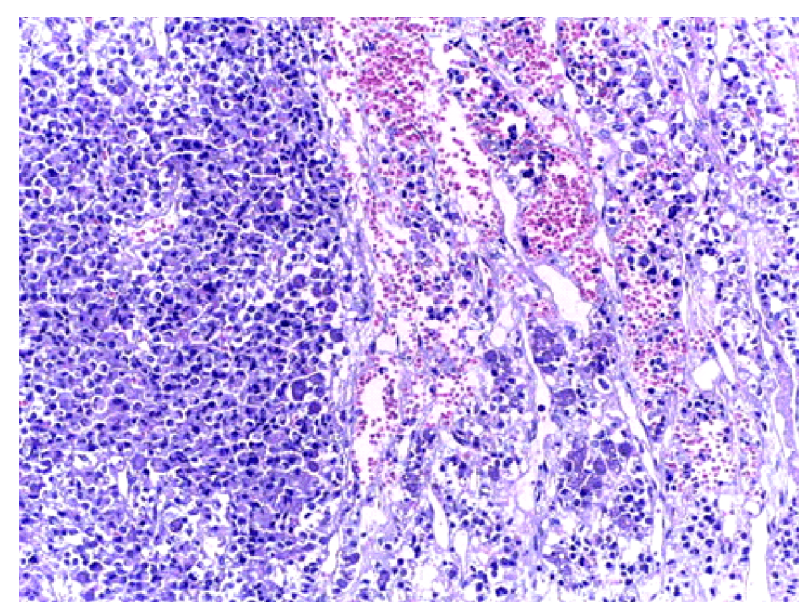

Figure 6 - Histological report in a case of GHproducing pituitary adenoma with clinical phenotype of acromegaly (HE staining, $\times 200)$. This is the case of young acromegalic male diagnosed with a large pituitary macroadenoma who as first referred for pituitary neurosurgery. The capture is provided after selective transsphenoidal hypophysectomy. GH: Growth hormone; HE: Hematoxylin-Eosin.
Recently, the immunostaining of tumoral somatotroph cells became important because therapy response to SSTAs is modulated by SSTRs expression and it might predict the type of response thus it indicates which SSTA should be used [2, 35, 40, 41] (Figure 7, A and B). As mentioned, the focus in on SSTR2 and SSTR5: if a somatotropinoma has mostly type 2 is more likely that acromegaly will be controlled with first line medical SSTAs molecules, while in tumors with type 5 preponderance, the subjects become candidates to Pasireotide in active disease under first generation SSTAs [42-44]. Pasireotide is a multi-targeted analogue, meaning that it binds mainly SSTR5 but also SSTR1, SSTR2, and SSTR3 [23]. Known the SSTRs configuration at somatotropinoma level, we may predict the response to therapy $[45,46]$. There is still controversial issue related to cost-effective approach if SSTRs immunostaining should be routinely performed in each tumor or therapeutic test with both SSTRAs generations (Pasireotide is acromegaly is active under Octreotide/Lanreotide) is a better solution $[45,46]$. Further standard protocols are expected in order to refine case-treating strategies combining endocrine profile and immunochemistry report.
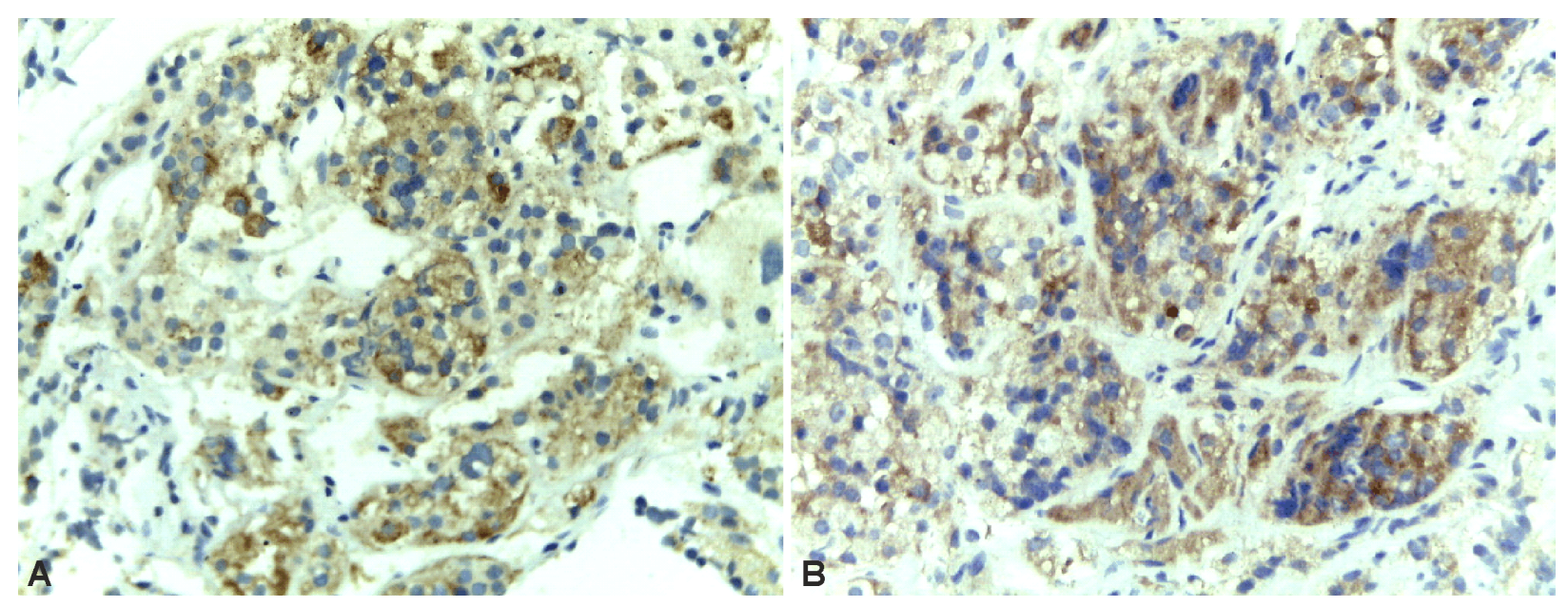

Figure 7 - Immunohistochemistry report: SSTRs in somatotroph cells of somatotropinoma (histological report was introduced above). (A) SSTR2 positive with moderate expression (of 33-66\%) in tumoral cells, IRS of 4 (intermediate score), SSTR2 polyclonal antibody kit, 1:75 dilution $(\times 200)$. (B) SSTR5 with moderate-to-high expression (>66\%) in tumoral cells, IRS of 6 (intermediate score), SSTR5 polyclonal antibody kit, 1:200 dilution ( $\times 400)$. IRS: Immunoreactive score; SSTRs: Somatostatin receptors.

\section{Discussions}

\section{Controversies}

SSTRs assays in daily clinical practice represent a major step ahead that improves the medical approach thus the prognosis of acromegaly. This topic is very recent, and some data are still necessary to better place the SSTRs immunostaining in clinical guidelines of acromegaly. Current limits of the topic are related to the fact that acromegaly treatment still represents a challenge in daily practice since routine tests of SSTR immunoreactions are not use. Also, the national protocol of SSTA reimbursement should include SSTR immunohistochemistry in order to choose the adequate line of medical therapy in patients with post-operative active disease. Moreover, another current limit of SSTR immunostaining is represented by the need of homogenous scales of assessment. However, the key message is the fact that understanding the immunochemistry profile is the pivotal approach in choosing the medical therapy for active acromegaly after neurosurgery was unsuccessful. Even the topic is rather a cutting edge in acromegaly approach; in the future, this will become a standard care in acromegalic subjects who were first treated with surgical intervention as the current guidelines indicate. Knowing the immunochemistry profile represents probably also a more cost-efficient approach since first live versus second line medication response depends on SSTR profile. A paper released in 2019 included as predictive marker of postsurgical therapy that SSTR expression is needed to assess the type of response to medical therapy with SSTAs [47]. But the immunohistochemistry of somatotropinoma is a part of the complex panel of predictive factors in addition to hormonal assays and imagery appearance of the tumor [47]. 


\section{Integrating the immunochemistry profile in daily routine practice}

The assessment of SSTRs is part of a larger frame that includes the use of immunochemistry in usual practical approach of tumors that exerts hormonal activity or even those detected as incidentalomas like neuroendocrine neoplasia or ovarian tumors [48-50]. NETs represent a large area of diseases located at any organ where a variety of SSTRs combinations are registered [48-51]. The present of the hormonal receptors at the surface of the tumor allows a new route of therapy including radiolabeled peptides [51]. Regarding the subtypes of SSTRs, the type 2 plays the major role because it is positive in most gastrointestinal neuroendocrine neoplasia [51]. It seems that overexpression of type 2 SSTRs goes through their up-regulation probably due to epigenetic factors [51]. Currently, SST-like molecules (or analogues) are used for tumors with active neuroendocrine profile but for the future antagonists of SST might find a place in the treatment regimens of mentioned tumors [51]. In rare cases of NETs that lack the expression of SSTR type 2, the role of SSTAs as part of therapeutical management is limited [51]. In addition to SSTRs configuration, other neuroendocrine markers are useful for immunostaining assays of NETs like chromogranin A (in association with blood assessment) or synaptophysin, etc. [52]. The blood neuroendocrine markers profile also includes serotonin or neuron-specific enolase, while for 24-hour urine the 5-hydroxyindoleacetic acid evaluation is useful $[52,53]$. SSTRs domain is actually more complex [54]. Currently, their labelling with tracers like ${ }^{68}$ Gallium $\left({ }^{68} \mathrm{Ga}\right)$ represents an elegant approach for advances imaging techniques like ${ }^{68} \mathrm{Ga}-\mathrm{SSTR}$ positron emission tomography $\left({ }^{68} \mathrm{Ga}-\mathrm{SSTR}-\mathrm{PET}\right)$ [54]. The use of ${ }^{68} \mathrm{Ga}$-SSTR-PET may become an independent prognostic tool as pointed by a meta-analysis published in 2019 by Lee $\&$ Kim [54]. The above-mentioned article includes eight studies comprising almost 500 patients with NETs of different grades regarding the differentiation profile [54]. The results of ${ }^{68} \mathrm{Ga}-\mathrm{SSTR}-\mathrm{PET}$ analysis as predictor factor seem even more important than the tumor site or the type of tracer [54]. PET imaging based on SSTRs overexpression at the level of NETs (traditionally at gastro-entero-pancreatic site) is mostly targeted to SSTR2 [55]. ${ }^{68} \mathrm{Ga}$-Dotatate-PET offers the advantages of a relatively low radiation dose in association to the possibility of results quantification and it seems superior to ${ }^{111}$ Indium $\left({ }^{111} \mathrm{In}\right)$-Pentetreotide according to some studies [55]. However, the use of SSTR imaging techniques is not adequate for a pituitary somatotropinoma in daily practice.

\section{Conclusions}

Immunoreactive markers like SSTRs are the U-turn in clinical practice regarding somatotropinomas since the configuration of subtypes 2 and 5 explains the responsiveness to medical therapy like SSTA. Further achievement of disease control is imperiously necessary since the condition has an increased rate of morbidity and mortality.

\section{Conflict of interests}

The authors declare that they have no conflict of interests.

\section{Acknowledgments}

The immunohistochemistry capture of the SSTRs was based on Thermo Fisher polyclonal SSTR2 and SSTR5 antibody kit provided by unrestricted Novartis grant. None of the figures has been priory published.

\section{References}

[1] Ben-Shlomo A, Liu NA, Melmed S. Somatostatin and dopamine receptor regulation of pituitary somatotroph adenomas. Pituitary, 2017, 20(1):93-99. https://doi.org/10.1007/s11102-016-0778-2 PMID: 27900635

[2] Dineen R, Stewart PM, Sherlock M. Acromegaly. QJM, 2017, 110(7):411-420. https://doi.org/10.1093/qjmed/hcw004 PMID: 26873451

[3] Franck SE, Gatto F, van der Lely AJ, Janssen JAMJL, Dallenga AHG, Nagtegaal AP, Hofland LJ, Neggers SJCMM. Somatostatin receptor expression in $\mathrm{GH}$-secreting pituitary adenomas treated with long-acting somatostatin analogues in combination with pegvisomant. Neuroendocrinology, 2017, 105(1):44-53. https://doi.org/10.1159/000448429 PMID: 27455094 PMCID: PMC5475231

[4] Kasajima A, Papotti M, Ito W, Brizzi MP, La Salvia A, Rapa I, Tachibana T, Yazdani S, Sasano H, Volante M. High interlaboratory and interobserver agreement of somatostatin receptor immunohistochemical determination and correlation with response to somatostatin analogs. Hum Pathol, 2018, 72:144-152. https:// doi.org/10.1016/j.humpath.2017.11.008 PMID: 29180250

[5] Paragliola RM, Corsello SM, Salvatori R. Somatostatin receptor ligands in acromegaly: clinical response and factors predicting resistance. Pituitary, 2017, 20(1):109-115. https://doi.org/10. 1007/s11102-016-0768-4 PMID: 27778296

[6] Rafferty J, Nagaraj H, McCloskey AP, Huwaitat R, Porter S, Albadr A, Laverty G. Peptide therapeutics and the pharmaceutical industry: barriers encountered translating from the laboratory to patients. Curr Med Chem, 2016, 23(37):42314259. https://doi.org/10.2174/0929867323666160909155222 PMID: 27633684

[7] Venegas-Moreno E, Flores-Martinez A, Dios E, VazquezBorrego MC, Ibañez-Costa A, Madrazo-Atutxa A, Japón MA, Castaño JP, Luque RM, Cano DA, Soto-Moreno A. E-cadherin expression is associated with somatostatin analogue response in acromegaly. J Cell Mol Med, 2019, 23(5):3088-3096. https://doi.org/10.1111/jcmm.13851 PMID: 30843342 PMCID: PMC6484433

[8] Volante M, Brizzi MP, Faggiano A, La Rosa S, Rapa I, Ferrero A, Mansueto G, Righi L, Garancini S, Capella C, De Rosa G, Dogliotti L, Colao A, Papotti M. Somatostatin receptor type 2A immunohistochemistry in neuroendocrine tumors: a proposal of scoring system correlated with somatostatin receptor scintigraphy. Mod Pathol, 2007, 20(11):1172-1182. https:// doi.org/10.1038/modpathol.3800954 PMID: 17873898

[9] Cuevas-Ramos D, Fleseriu M. Somatostatin receptor ligands and resistance to treatment in pituitary adenomas. J Mol Endocrinol, 2014, 52(3):R223-R240. https://doi.org/10.1530/ JME-14-0011 PMID: 24647046

[10] Sun L, Coy DH. Somatostatin and its analogs. Curr Drug Targets, 2016, 17(5):529-537. https://doi.org/10.2174/13894 50116666141205163548 PMID: 26951062

[11] Günther T, Tulipano G, Dournaud P, Bousquet C, Csaba Z, Kreienkamp HJ, Lupp A, Korbonits M, Castaño JP, Wester HJ, Culler M, Melmed S, Schulz S. International Union of Basic and Clinical Pharmacology. CV. Somatostatin receptors: structure, function, ligands, and new nomenclature. Pharmacol Rev, 2018, 70(4):763-835. https://doi.org/10.1124/pr.117.01 5388 PMID: 30232095 PMCID: PMC6148080

[12] Soukup J, Kasparova P, Kohout A, Rychly B, Skarkova V, Syrucek M, Gabalec F. Evaluation of expression of somatostatin receptor 1, 2, 3, 5 and dopamine D2 receptor in spindle cell oncocytomas of posterior pituitary. Pituitary, 2019, 22(1): 70-78. https://doi.org/10.1007/s11102-018-00935-7 PMID: 30607746

[13] Fotouhi O, Zedenius J, Höög A, Juhlin CC. Regional differences in somatostatin receptor 2 (SSTR2) immunoreactivity is coupled to level of bowel invasion in small intestinal neuroendocrine tumors. Neuro Endocrinol Lett, 2018, 39(4):305-309. PMID: 30531706 
[14] Öberg K. The genesis of the neuroendocrine tumors concept from Oberndorfer to 2018. Endocrinol Metab Clin North Am, 2018, 47(3):711-731. https://doi.org/10.1016/j.ecl.2018.05.003 PMID: 30098726

[15] Leijon H, Remes S, Hagström J, Louhimo J, Mäenpää H, Schalin-Jäntti C, Miettinen M, Haglund C, Arola J. Variable somatostatin receptor subtype expression in 151 primary pheochromocytomas and paragangliomas. Hum Pathol, 2019, 86:66-75. https://doi.org/10.1016/j.humpath.2018.11.020 PMID: 30529752

[16] Poiană C, Neamţu MC, Avramescu ET, Carşote M, Trifănescu R, Terzea D, Neamţu OM, Ferechide D, Dănciulescu Miulescu R. The poor prognosis factors in G2 neuroendocrine tumor. Rom J Morphol Embryol, 2013, 54(3 Suppl):717-720. PMID: 24322017

[17] Poiană C, Neamţu MC, Avramescu ET, Carşote M, Trifănescu R, Terzea D, Neamţu OM, Dănciulescu Miulescu R. The dedifferentiation of neuroendocrine tumor metastases: myth or reality? Rom J Morphol Embryol, 2013, 54(1):201-203. PMID: 23529331

[18] Poiană C, Carşote M, Ardeleanu C, Terzea D, Avramescu ET, Neamţu MC, Dănciulescu Miulescu R. The value of the immunohistochemistry in a case of gastric neuroendocrine tumor and thyroid metastasis. Rom J Morphol Embryol, 2011, 52(1):187-192. PMID: 21424054

[19] Carmona Matos DM, Jang S, Hijaz B, Chang AW, Lloyd RV, Chen $\mathrm{H}$, Jaskula-Sztul R. Characterization of somatostatin receptors (SSTRs) expression and antiproliferative effect of somatostatin analogues in aggressive thyroid cancers. Surgery, 2019, 165(1):64-68. https://doi.org/10.1016/j.surg.2018.05.077 PMID: 30415874

[20] Herac M, Niederle B, Raderer M, Krebs M, Kaserer K, Koperek O. Expression of somatostatin receptor 2A in medullary thyroid carcinoma is associated with lymph node metastasis. APMIS, 2016, 124(10):839-845. https://doi.org/10.1111/apm. 12584 PMID: 27539746

[21] Kaemmerer D, Athelogou M, Lupp A, Lenhardt I, Schulz S, Luisa P, Hommann M, Prasad V, Binnig G, Baum RP. Somatostatin receptor immunohistochemistry in neuroendocrine tumors: comparison between manual and automated evaluation. Int J Clin Exp Pathol, 2014, 7(8):4971-4980. PMID: 25197368 PMCID: PMC4152058

[22] Schulz S, Pauli SU, Schulz S, Händel M, Dietzmann K, Firsching R, Höllt V. Immunohistochemical determination of five somatostatin receptors in meningioma reveals frequent overexpression of somatostatin receptor subtype $\mathrm{sst}_{2 \mathrm{~A}}$. Clin Cancer Res, 2000, 6(5):1865-1874. PMID: 10815909

[23] Chalabi M, Duluc C, Caron P, Vezzosi D, Guillermet-Guibert J, Pyronnet S, Bousquet C. Somatostatin analogs: does pharmacology impact antitumor efficacy? Trends Endocrinol Metab, 2014, 25(3):115-127. https://doi.org/10.1016/j.tem.2013.11. 003 PMID: 24405892

[24] Gatto $F$, Arvigo $M$, Amarù J, Campana $C$, Cocchiara F, Graziani G, Bruzzone E, Giusti M, Boschetti M, Ferone D. Cell specific interaction of pasireotide: review of preclinical studies in somatotroph and corticotroph pituitary cells. Pituitary, 2019, 22(1):89-99. https://doi.org/10.1007/s11102-018-0926-y PMID: 30483918

[25] Fleseriu M, Rusch E, Geer EB; ACCESS Study Investigators. Safety and tolerability of pasireotide long-acting release in acromegaly - results from the acromegaly, open-label, multicenter, safety monitoring program for treating patients who have a need to receive medical therapy (ACCESS) study. Endocrine, 2017, 55(1):247-255. https://doi.org/10.1007/s12 020-016-1182-4 PMID: 27896545 PMCID: PMC5225222

[26] de Herder WW. When and how to use somatostatin analogues Endocrinol Metab Clin North Am, 2018, 47(3):549-555. https:// doi.org/10.1016/j.ecl.2018.04.010 PMID: 30098715

[27] Ozkaya HM, Comunoglu N, Sayitoglu M, Keskin FE, Firtina S, Khodzhaev K, Apaydin T, Gazioglu N, Tanriover N, Oz B, Kadioglu P. Germline mutations of aryl hydrocarbon receptorinteracting protein $(A I P)$ gene and somatostatin receptor 1-5 and AIP immunostaining in patients with sporadic acromegaly with poor versus good response to somatostatin analogues. Pituitary, 2018, 21(4):335-346. https://doi.org/10.1007/s111 02-018-0876-4 PMID: 29455389
[28] Tritos NA, Biller BMK. Medical therapy for Cushing's syndrome in the twenty-first century. Endocrinol Metab Clin North Am, 2018, 47(2):427-440. https://doi.org/10.1016/j.ecl.2018.01.006 PMID: 29754642

[29] Sawicka-Gutaj N, Owecki M, Ruchala M. Pasireotide mechanism of action and clinical applications. Curr Drug Metab, 2018, 19(10):876-882. https://doi.org/10.2174/13892002196 66180328113801 PMID: 29595102

[30] Zawada NB, Kunert-Radek J, Pawlikowski M, Pisarek $H$, Radek M. An evaluation of the effects of somatostatin analogue therapy in non-functioning pituitary adenomas in comparison to acromegaly. Endokrynol Pol, 2016, 67(3):292-298. https:// doi.org/10.5603/EP.a2016.0043 PMID: 27345147

[31] Bousquet C, Lasfargues C, Chalabi M, Billah SM, Susini C, Vezzosi D, Caron P, Pyronnet S. Clinical review: current scientific rationale for the use of somatostatin analogs and mTOR inhibitors in neuroendocrine tumor therapy. J Clin Endocrinol Metab, 2012, 97(3):727-737. https://doi.org/10. 1210/jc.2011-2088 PMID: 22170729

[32] Maffezzoni F, Formenti AM, Mazziotti G, Frara S, Giustina A. Current and future medical treatments for patients with acromegaly. Expert Opin Pharmacother, 2016, 17(12):16311642. https://doi.org/10.1080/14656566.2016.1199687 PMID: 27352098

[33] Zahr R, Fleseriu M. Updates in diagnosis and treatment of acromegaly. Eur Endocrinol, 2018, 14(2):57-61. https://doi. org/10.17925/EE.2018.14.2.57 PMID: 30349595 PMCID: PMC6182922

[34] Leonart LP, Borba HHL, Ferreira VL, Riveros BS, Pontarolo R. Cost-effectiveness of acromegaly treatments: a systematic review. Pituitary, 2018, 21(6):642-652. https://doi.org/10.1007/ s11102-018-0908-0 PMID: 30159696

[35] Christofides EA. Clinical importance of achieving biochemical control with medical therapy in adult patients with acromegaly. Patient Prefer Adherence, 2016, 10:1217-1225. https://doi. org/10.2147/PPA.S102302 PMID: 27471378 PMCID: PMC 4948729

[36] Di Bella G, Colori B, Scanferlato R. The over-expression of $\mathrm{GH} / \mathrm{GHR}$ in tumour tissues with respect to healthy ones confirms its oncogenic role and the consequent oncosuppressor role of its physiological inhibitor, somatostatin: a review of the literature. Neuro Endocrinol Lett, 2018, 39(3):179-188. PMID: 30431745

[37] AIDallal S. Acromegaly: a challenging condition to diagnose. Int J Gen Med, 2018, 11:337-343. https://doi.org/10.2147/ IJGM.S169611 PMID: 30197531 PMCID: PMC6112775

[38] Fuentes-Fayos AC, García-Martínez A, Herrera-Martínez AD, Jiménez-Vacas JM, Vázquez-Borrego MC, Castaño JP, Picó A, Gahete MD, Luque RM. Molecular determinants of the response to medical treatment of growth hormone secreting pituitary neuroendocrine tumors. Minerva Endocrinol, 2019, 44(2):109128. https://doi.org/10.23736/S0391-1977.19.02970-5 PMID: 30650942

[39] Lopes MBS. Growth hormone-secreting adenomas: pathology and cell biology. Neurosurg Focus, 2010, 29(4):E2. https:// doi.org/10.3171/2010.7.FOCUS10169 PMID: 20887127

[40] Treppiedi D, Peverelli E, Giardino E, Ferrante E, Calebiro D, Spada A, Mantovani G. Somatostatin receptor type 2 (SSTR2) internalization and intracellular trafficking in pituitary $\mathrm{GH}$ secreting adenomas: role of scaffold proteins and implications for pharmacological resistance. Horm Metab Res, 2017, 49(4): 259-268. https://doi.org/10.1055/s-0042-116025 PMID: 27632151

[41] Brzana J, Yedinak CG, Gultekin SH, Delashaw JB, Fleseriu M. Growth hormone granulation pattern and somatostatin receptor subtype 2A correlate with postoperative somatostatin receptor ligand response in acromegaly: a large single center experience. Pituitary, 2013, 16(4):490-498. https://doi.org/10.1007/s111 02-012-0445-1 PMID: 23184260

[42] Colao A, Grasso LFS, Giustina A, Melmed S, Chanson P, Pereira AM, Pivonello R. Acromegaly. Nat Rev Dis Primers, 2019, 5(1):20. https://doi.org/10.1038/s41572-019-0071-6 PMID: 30899019

[43] Chiloiro S, Giampietro A, Bianchi A, Tartaglione T, Bima C, Vita MG, Spinello M, Pontecorvi A, De Marinis L. Acromegaly can be cured by first-line pasireotide treatment? Endocrine, 2019, 64(1):196-199. https://doi.org/10.1007/s12020-019-01 874-4 PMID: 30798431 
[44] Coopmans EC, Muhammad A, van der Lely AJ, Janssen JAMJL, Neggers SJCMM. How to position pasireotide LAR treatment in acromegaly. J Clin Endocrinol Metab, 2019, 104(6):19781988. https://doi.org/10.1210/jc.2018-01979 PMID: 30608534

[45] Orlewska E, Stępień R, Orlewska K. Cost-effectiveness of somatostatin analogues in the treatment of acromegaly. Expert Rev Pharmacoecon Outcomes Res, 2019, 19(1):15-25. https:// doi.org/10.1080/14737167.2018.1513330 PMID: 30122081

[46] Shimon I, Adnan Z, Gorshtein A, Baraf L, Saba Khazen N, Gershinsky M, Pauker Y, Abid A, Niven MJ, Shechner C, Greenman Y. Efficacy and safety of long-acting pasireotide in patients with somatostatin-resistant acromegaly: a multicenter study. Endocrine, 2018, 62(2):448-455. https://doi.org/10.10 07/s12020-018-1690-5 PMID: 30051198

[47] Ezzat S, Caspar-Bell GM, Chik CL, Denis MC, Domingue MĖ Imran SA, Johnson MD, Lochnan HA, Grégoire Nyomba BL, Prebtani A, Ridout R, Ramirez JAR, Van Uum S. Predictive markers for postsurgical medical management of acromegaly: a systematic review and consensus treatment guideline. Endocr Pract, 2019, 25(4):379-393. https://doi.org/10.4158/EP-20180500 PMID: 30657362

[48] Gheorghisan-Galateanu AA, Carsote M, Valea A. Incidentaloma: from general practice to specific endocrine frame. J Pak Med Assoc, 2017, 67(6):917-922. PMID: 28585593

[49] Gheorghisan-Galateanu AA, Terzea D, Valea A, Carsote M. Menopausal androgen excess - associated cardio-metabolic risk: clues for ovarian Leydig cell tumour (case report and minireview of literature). Acta Endocrinol (Bucharest), 2017, 13(3): 356-363. https://doi.org/10.4183/aeb.2017.356 PMID: 31149200 PMCID: PMC6516568
[50] Carşote M, Păun S, Neamţu MC, Avramescu ET, losif C, Terzea D, Constantinoiu S, Dănciulescu Miulescu R, Neamţu OM, Poiană $\mathrm{C}$. The immunohistochemistry aspects in two cases of neurofibromatosis-associated abdominal tumors. Rom J Morphol Embryol, 2012, 53(2):401-405. PMID: 22732814

[51] Refardt J, Hofland J, Kwadwo A, Nicolas GP, Rottenburger C, Fani M, Wild D, Christ E. Theranostics in neuroendocrine tumors: an overview of current approaches and future challenges. Rev Endocr Metab Disord, 2020 Jun 3. https://doi.org/10.1007/ s11154-020-09552-x PMID: 32495250

[52] Poiana C, Carsote M, Trifanescu R, Terzea D, Croitoru A. Case study of appendiceal carcinoid during pregnancy. J Med Life, 2012, 5(3):325-328. PMID: 23049637 PMCID: PMC 3465003

[53] Carsote M, Valea A. Neuroendocrine tumours: 2016 update. Acta Medica Transilvanica, 2016, 21(3):41-44. http://www. amtsibiu.ro/Arhiva/2016/nr3-en/Carsote.pdf

[54] Lee DY, Kim YI. Prognostic value of maximum standardized uptake value in ${ }^{68} \mathrm{Ga}$-somatostatin receptor positron emission tomography for neuroendocrine tumors: a systematic review and meta-analysis. Clin Nucl Med, 2019, 44(10):777-783. https://doi.org/10.1097/RLU.0000000000002694 PMID: 31283601

[55] Ivanidze J, Roytman M, Sasson A, Skafida M, Fahey TJ 3rd, Osborne JR, Dutruel SP. Molecular imaging and therapy of somatostatin receptor positive tumors. Clin Imaging, 2019, 56: 146-154. https://doi.org/10.1016/j.clinimag.2019.04.006 PMID: 31121520

\section{Corresponding author}

Mara Carsote, Lecturer, MD, PhD, Department of Endocrinology, Carol Davila University of Medicine and Pharmacy, C. I. Parhon National Institute of Endocrinology, 34-38 Aviatorilor Avenue, Sector 1, 011863 Bucharest, Romania; Phone +40744-851 934, e-mail: carsote_m@hotmail.com 